\title{
Research on Aesthetic Education in College Ideological and Political Education
}

\author{
Junli Wang \\ Weinan Normal University, Weinan, Shaanxi, 714099
}

Keywords: colleges and universities; Ideological and Political Education; aesthetic education

\begin{abstract}
Under the new circumstances of the new environment, the quality education in colleges and universities emphasizes the improvement of the aesthetic and humanistic qualities of college students in order to promote educational equity, and the integration of ideological and political education and aesthetic education in colleges and universities has risen to the policy level. Therefore, the social requirements for cultivating college students' ideological and political qualities are increasing. The contents of ideological and political education in colleges and universities are the same as those of aesthetic education goals. Integrating aesthetic education into ideological and political education in colleges and universities can improve college students' aesthetic ability and promote their all-round development. The goals of ideological and political education and aesthetic education are consistent and the contents are united. Therefore, the combination of the two can achieve mutual promotion and complement each other. However, in the actual education process, there are still many problems in the integration of aesthetic education and ideological and political education. This paper mainly elaborates the strategy of improving the effectiveness of aesthetic education in ideological and political education through the method of problem analysis.
\end{abstract}

\section{Introduction}

The integration of aesthetic education into ideological and political education in colleges and universities has its important significance in the following aspects: First, it fosters the noble moral sentiment of college students. The main role of aesthetic education is to "cite the good by the United States." Truth and goodness are the important connotations of beauty. Morality is not only a code of conduct that social citizens need to follow, but also an important criterion for judging good and evil. Integrating aesthetic education into moral education can enable students to find truth, goodness and beauty in their aesthetic activities, cultivate their positive and progressive attitude towards life, and improve their ability to discover the beauty and pursue goodness, thereby enhancing their moral sentiments. Second, healthy personality. In the information age, the social environment is becoming more and more complicated. Various complex social psychology and bad thoughts will have an important impact on the development of college students' personality. Positive influences can certainly promote the growth of college students, but negative influences will make the university students feel emotional and rational. Being out of balance, it will affect the personality development of college students over time. The aesthetic activities can promote the aesthetic subject into a harmonious aesthetic state in which the sensibility and rationality are mutually in harmony, and balance the sensibility and rationality so as to shape the healthy personality of college students. Again, aesthetic education can help college students consciously resist bad erosion. Aesthetic education can improve the students' aesthetic conception and cultivate their good aesthetic consciousness. The melding of good things can improve college students' aesthetic ability, promote their aesthetic pursuit to be more inclined to the social mainstream values, and guide students to discover beauty and criticism in complex social phenomena. Ugly, help him consciously resist the bad erosion of ugly things. Finally, improve students' innovative ability. Truth and goodness are two important categories of beauty. Aesthetic activities can not only improve students' humanistic feelings, but also stimulate students' desire for truth and curiosity. Aesthetic education is based on the perspective of image thinking. Students are visualized and visualized education can play a role in the development of the right brain. Therefore, aesthetic education plays an important role in 
fostering people's image thinking. Image thinking further promotes student innovation. With the development of ability, aesthetic education can cultivate the innovative ability of college students.

\section{The Problems Existing in Aesthetic Education in Ideological and Political Education in Colleges and Universities}

Although the majority of ideological and political educators have realized the importance of aesthetic education in improving the overall quality of college students, there is still a narrow aesthetic education concept in the actual teaching process. Many teachers believe that aesthetic education is only through music, art, film and television. Improve students' aesthetic ability. This erroneous cognition does not accurately distinguish the relationship between art education and aesthetic education. In fact, art education is a form and part of aesthetic education. The connotation of aesthetic education is more abundant, such as the beauty of the society, the beauty of life, the beauty of science, etc. The narrow aesthetic education will cause teachers and students to gradually lose the motivation of aesthetic education. Educators themselves believe that aesthetic education is optional, students are less aware of the important role of aesthetic education, and the final result is that aesthetic education is in the form.

The "ideological, political and moral basis and legal accomplishment" is a compulsory subject for ideological and political education of college students. Although it contains Marxist-Leninist theoretical knowledge and content close to the students' outlook on life and values, the educational effect still needs to be strengthened. The theory of Marxism in China is the main content of ideological and political education in colleges and universities. Although it involves the education of traditional moral concepts, Chinese traditional culture and education, it does not emphasize the importance of aesthetics, and lacks some of the changes in the times and the needs of the current social Content; and aesthetic education in colleges and universities pays too much attention to short-term educational achievements, ignoring the role played by aesthetic education in setting up the correct values of college students and perfecting their personality.

Aesthetic education, aesthetic sense education and aesthetic emotion cultivation are important forms of implementing aesthetic education. However, in practical education, the form of aesthetic education in Chinese universities is still very simple. At the level of aesthetic knowledge education, aesthetic knowledge education is still confined to classroom teaching. A single classroom form cannot mobilize students' aesthetic interests. As time passes, students are less interested in aesthetic education. However, in the aspect of cultivating aesthetic sense, the continuous expansion of colleges and universities has caused a serious shortage of aesthetic education resources. Most colleges and universities do not carry out aesthetic education practice activities. Some colleges and universities mainly organize aesthetic activities through students, and students generally lack aesthetic ability and aesthetic cultivation. The practical effect of aesthetic practice cannot be guaranteed, and it is difficult to reflect the function of ideological and political education in colleges and universities. In addition, cultivating students' aesthetic emotion is the highest form of aesthetic education, but because aesthetic education only stays in the classroom, the influence of aesthetic emotion becomes the weakest link in aesthetic education.

\section{Improve the Effectiveness of Aesthetic Education in Ideological and Political Education}

To solve the problems existing in aesthetic education in ideological and political education in colleges and universities, it is suggested that improvement should be made in the following aspects:

Although everybody often mentions verbally that "the construction of ideas is the precursor to aesthetic education", there are very few people who really value aesthetic education ideologically. School administrators manage based on the perspective of school business development. Their focus is naturally on performance, professional construction, graduation assignment, etc., and rarely think about aesthetic education ideological construction. Some educators, because of their lack of professional aesthetic education ability, believe that aesthetic education is a long-term activity and their effects cannot be reflected by quantitative indicators. Therefore, more practical and affordable 
things in daily teaching management are for them. It is more attractive. For students, schools and teachers don't pay much attention to aesthetic education. They are not aware of the profound impact that aesthetic education will have on their future lives. Therefore, in practical teaching, we must start from the three levels of school administrators, aesthetic educators, and students to clarify the content of aesthetic education. College administrators should realize that the focus of ideological and political education is to help students establish a scientific and correct life. Outlook and values, while aesthetic education is a long-term approach; educators must change the ideology of utilitarian education, clarify the transcendence of aesthetic education, and regard aesthetic education as their own obligations and responsibilities; college students must Under the guidance of schools and teachers, the long-term role of aesthetic education is fully recognized, and learning enthusiasm and initiative are enhanced.

In view of the current limitations of colleges and universities on aesthetic education, it is suggested that the content of ideological and political education should be enhanced and the education content of aesthetic education should be enriched. As mentioned above repeatedly, the connotation of the United States is true and good. The fundamental attribute of ideological and political education is truth. Truth is not only true, but also loyalty and the true meaning of feelings. Therefore, in ideological and political education, the teacher should tell the truth with sincere emotion. It touched and touched a student while moving itself. Ideological and political education must be based on the principle of seeking truth from facts and truth, based on objective things, and eliminate false air to better touch the soul of college students. For example, in the application of typical advanced character deeds, we must carry out true carving of the main characters, and must not be overly beautified to make the typical characters out of reality, which makes students have conflicting ideological and political education. Good education focuses on dedication and value, and ideological and political education must be based on principles and dedication; and students must also fully utilize their own values through various practical activities. The aesthetic education in ideological and political education is a combination of dedication and organic values. It not only allows students to realize the meaning of selfless devotion to the country, the people, and the society, but also takes care of the students' own value development and meets the spirit of the students. Demand and material needs stimulate students' enthusiasm for learning.

The meaning of the United States is not immutable. The specific environment is different, and the connotation of the beauty will be different. In order to develop aesthetic education in ideological and political education, we must adopt a variety of colorful, lively and diverse forms of education in order to stimulate students' enthusiasm for learning. Aesthetic education should closely follow the actual needs of the development of college students, keep up with the pace of the times, conform to the development of the times, and reflect the characteristics of the times and progress. In addition to adopting traditional education methods in the actual education process, we must further innovate the form of ideological and political education and incorporate advanced teaching techniques and teaching methods so that the ideological and political education in universities reflects the beauty of technological innovation. On the one hand, we should recommend outstanding musical dramas, book works, and film and television to undergraduate students according to the educational standards of thought and art, and introduce typical advanced figures. Through this traditional teaching method, the aesthetic ability of undergraduates is maintained at a relatively high level; on the other hand, According to the interests of college students, they should carry out diverse cultural and sports activities such as quizzes, ballad competitions, speech contests, etc., highlighting the entertaining characteristics of aesthetic education firearms, making college students feel emotional freedom and comfort, thereby strengthening the long-term aesthetic education. effect. Simply saying that the church makes students feel tired of learning, that ideological and political education, aesthetic education is nothing but empty talk, cliches, and the perception of aesthetic education also remains at the theoretical level. In the teaching activities, the idea of ideological and political education should be placed in the image of the United States, and the impact of the subtle influence on the college students should be aesthetically pleasing. Aesthetic education is essentially a kind of emotional influence, and the generation of emotion is evoked by the image of beauty. 
Undergraduates resonate in the image of the organic combination of love and beauty, gain emotional experience of emotions and emotions, and are influenced and nurtured to achieve the goal of ideological and political education. The ideological and political education must combine truth and esteem in a practical and realistic manner. The ideological and political education focuses on facts, reasoning, and convincing people with reason, but our object of education is also a person with complex emotions. This must be concerned with emotional factors. At the same time as Xiao Zhi Li and Li Zhifu, they are moved by emotions and emotional people. Only in this way can we truly convince people to arouse their enthusiasm and arouse their enthusiasm for the pursuit of truth and the pursuit of beauty.

\section{Conclusion}

In short, the pursuit of beauty is the nature of mankind. The more human subjectivity gains publicity, the more complete its essential power is. The more people must reform the world according to the laws of the United States, thereby promoting the continuous development of social civilization. In a new era and a new environment, colleges and universities are important positions for ideological and political education. As a kind of silent education, aesthetic education plays an important role in the overall development of students. It can cultivate their humanistic qualities, aesthetic qualities, and improve their overall quality. Improve their personality development. In the daily education process, we must face up to many problems in the content, form and concept of aesthetic education, and take targeted measures to improve. Of course, aesthetic education in colleges and universities is a long and arduous task, but I believe that as long as the majority of educators continue to summarize and continuously improve in practice, the functions of aesthetic education will inevitably be brought into full play, and personality integrity and aesthetic appreciation will be cultivated. Strong talents.

\section{References}

[1] Liu Xiangxin. On Aesthetic Education and Cultivation of Human Creativity[J]. Shandong Social Sciences, 2013, (5):82-83.

[2] Wang Zhe. A preliminary exploration of aesthetic education in college students' ideological and political work [J]. Journal of Guizhou Institute of Education: Social Sciences, 2017(7):19-20.

[3] Zhang Jun. The Integration of Aesthetic Education and Moral Education in College Students' Ideological and Political Education[J]. Journal of Panzhihua University, 2011(5):19-20.

[4] Jin Lianqi. On the Aesthetic Dimension of College Students' Ideological and Political Education[J]. Jiangsu Higher Education, 2010(5):118-119.

[5] Shi Hyeing, Xie Zhongyuan. The aesthetic construction of undergraduates' ideological and political education under the standard of position [J]. Heilongjiang Higher Education Research, 2017(2):89-91 